\title{
TOTAL METALS IN UNIVERSITY OF LAGOS WETLANDS AND SEDIMENTS AND THEIR SPATIAL DISTRIBUTION
}

\author{
*Kehinde Sowunmi, Soyebo Titilayo \& Lukman Sowunmi \\ *Department of Cell biology and Genetics, University of Lagos, Akoka, Yaba, Nigeria \\ Department of Applied Science, Ladoke Akintola University of Technology, Ogbomoso, Nigeria
}

\begin{abstract}
Wetlands are carriers of metals and organic pollutants from natural and anthropogenic sources. Studies have shown that sediments are sinks for these pollutants as they carry more than $99 \%$ of the total amount of metals which are released as soluble metals into the Lagoon. The University of Lagos, located at Akoka North eastern part of Yaba in Lagos Mainland runs along a highly industrialized and residential area. This paper reports the total metal concentrations in wetland and sediment and their seasonal variations. Wetland and sediment samples were collected for two seasons in 8 sampling sites. Results showed wetland data having lower concentrations of metals as compared to sediments. Wet season had higher concentrations of metals as compared to other season. Total concentrations in wetlands were $\mathrm{Cd}$ (1.0-6.0), $\mathrm{Cu}$ (1.0-11.0), $\mathrm{Cr}$ (0.3-82.7), $\mathrm{Zn}$ (2.7-65.0) and $\mathrm{Pb}$ (0.3-16.0) all in $\mu \mathrm{g}$ L-1 respectively. Statistical analysis showed that there was a significant difference between the wet and dry seasons for sediments. Cd was the only metal at acceptable levels while $\mathrm{Cr}, \mathrm{Cu}, \mathrm{Pb}$ and $\mathrm{Zn}$ concentrations all exceeded levels deemed acceptable by the SABS and the EPA. Therefore, the wetland is in poor health.
\end{abstract}

Keywords: heavy metals, seasonal variability, pollution, industries

\section{Introduction}

Heavy metals, such as lead and cadmium are considered pollutants because of their potential toxicity to plants, animals and human life (Banerjee et al., 2012). Anthropogenic and natural activities, from the surrounding environment are the main sources of river pollution (Kank1liç et al., 2013; Mutia et al., 2012). Direct influxes from industrial and agricultural activities are common and may be further supplemented by natural weathering. Physical parameters of wetlands and sediments are $\mathrm{pH}$, redox, electrical conductivity, dissolved oxygen and temperature. These contribute to the availability of heavy metals in the lagoon system, and these parameters are often included in various guidelines to monitor and control anthropogenic pollution of wetlands. Metal concentration and physical parameters are compared to wetland quality guidelines to protect the ecosystem (Farkas et al., 2007). The rate of water pollution varies seasonally, depending on discharge, flow rates and interactions with the environment (Tsai et al., 2007; USEPA, 2001). Seasons in Nigeria may be classified as dry or wet; the dry seasons. Studies have shown that watetlands and sediments have varying concentrations per season depending on the type of pollution and region (Kamau et al., 2008; Lokeshwari et al., 2006). Water usually shows high concentrations of metals during the dry season as there is no rapid movement, mixing and/or dilution caused by rainfall. In the dry season water levels reduce due to lower rainfall and evaporation, and precipitation of the metals leads to sediments accumulating most of the metals. Conversely during wet season, previously accumulated metals are released as a result of increased water flow, this is dependent on the physico chemical conditions present in the lagoon (Kamau et al., 2008).

The University of Lagos situated within Lagos Mainland LGA of Lagos state lies between latitude $03.2343^{\circ} \mathrm{E}-03.34554^{\circ} \mathrm{E}$ and longitude $06.2135^{\circ} \mathrm{N}-06.4323^{\circ} \mathrm{N}$. This area is host to many activities which are industrial (paint, machinery, and waste management) and agricultural (arable and livestock farming) based; these make extensive use of natural water resources. Water in the area is also used for recreational 
and domestic purposes. The aforementioned industrial activities are possible sources of heavy metals particularly (Cd, Cr, Cu, $\mathrm{Pb}$ and $\mathrm{Zn}$ ) contamination (Fatoki et al., 2002).

Investigations on organic pollutants within the system have previously been conducted while metal determination studies have been very limited and are not widely documented for possible pollutant inputs (Barratt, 2002; Dickens et al., 1998; Ramjatan et al., 2000).

One study was carried out in the Olifants River for a period of one year. The results showed high concentration of $\mathrm{Zn}, \mathrm{Pb}$ and $\mathrm{Cr}$ accumulated in different fish species at varying localities (Coetzee et al., 2002). The river had industries and sewage treatment works alongside it which were reported to affect its water quality. Okonkwo and Mothiba (2005) conducted a study on trace metals from Dzindi, Madanzhe and Mvudi rivers in South Africa. The concentrations of $\mathrm{Cd}$ and $\mathrm{Pb}$ among other measure metals exceeded the international guideline for drinking water (Okonkwo et al., 2004). This study measures the total concentrations of metals in the University of Lagos wetlands and sediments. A range of metals were screened in both water and sediment samples and $\mathrm{Cd}, \mathrm{Cr}, \mathrm{Cu}, \mathrm{Pb}$ and $\mathrm{Zn}$ were selected based on their toxicity, essentiality and detectability in samples. Arsenic and mercury for example, while highly toxic, were present at levels below the detection limits and hence were excluded from the list of the studied metals.

\section{Materials and Methods}

\subsection{Study Area}

The University of Lagos also called UNILAG, situated within Lagos Mainland LGA of Lagos state lies between latitude $03.2343^{\circ} \mathrm{E}-03.34554^{\circ} \mathrm{E}$ and longitude $06.2135^{\circ} \mathrm{N}-06.4323^{\circ} \mathrm{N}$. It is bounded on the north by Bariga, at the south by Onike and Iwaya, the east by Lagos Lagoon and at the west by Yaba.

The University of Lagos is an institution of higher learning founded in 1962. It presently has three campuses in Yaba and Surulere. The main campus which is of interest in this research is located at Akoka North eastern part of Yaba in Lagos Mainland LGA. It is largely surrounded by the scenic view of the Lagos Lagoon and with an area of 802 acres of land.

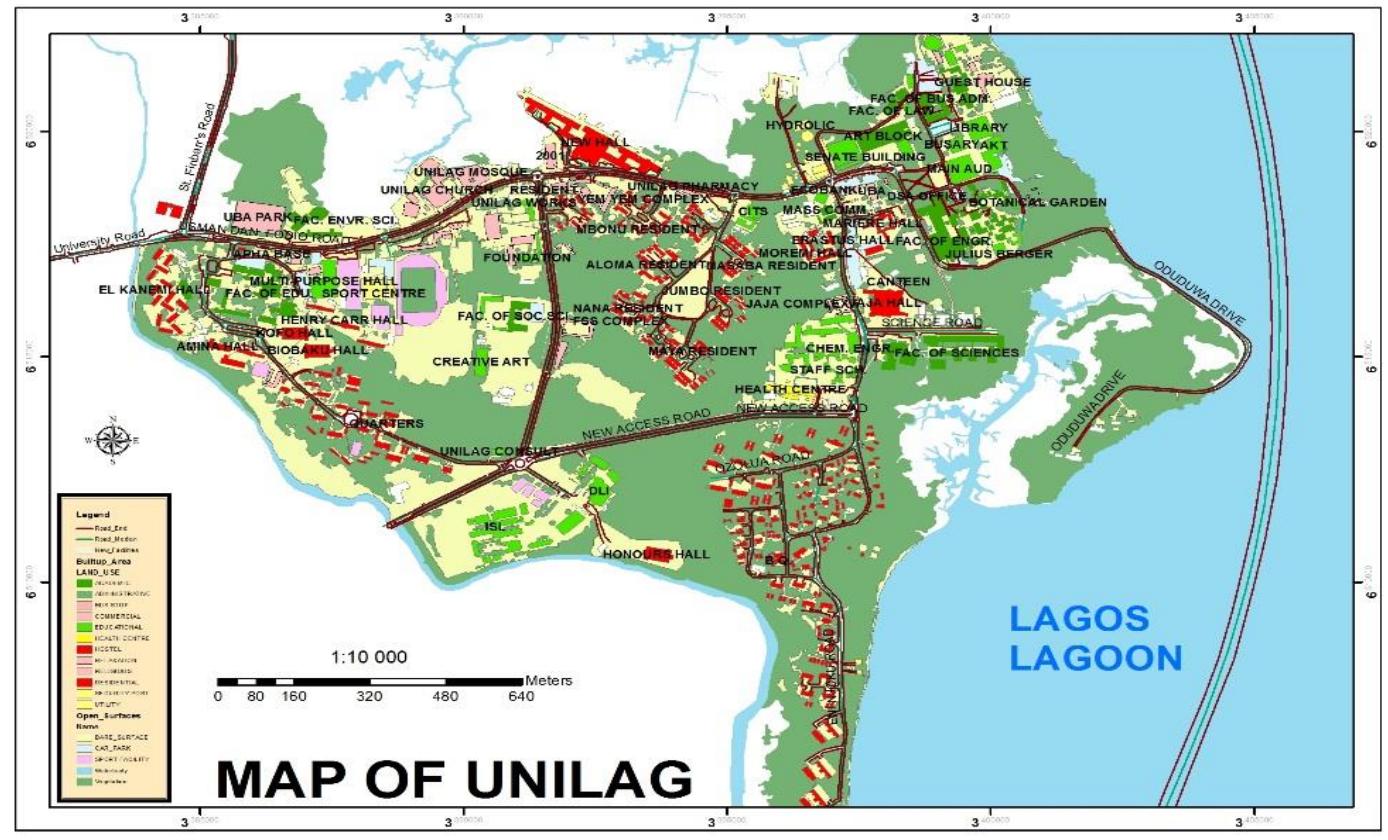

Figure 1: Existing digital map of UNILAG (Source: Department of Geography, university of Lagos.)

\subsection{Experimental}


This section encompasses the chemicals and instruments used in analysis of metals in wetlands and sediments.

\subsubsection{Chemicals}

The following chemicals were used; Nitric acid $\geq 69 \%$ (Merck), Hydrochloric acid $\geq 37 \%$ (Merck), 1000 ppm Cd standard (DLD Scientific), 1000 ppm Cr and 1000 ppm Pb standards (Fluka), 1000 ppm Cu and 1000 ppm Zn standards (Merck). Certified reference material NIST 2702 was from the NIST, Canada. Double distilled water was used throughout the study as blank and for making up standards and sediment samples.

\subsection{Instrumentation}

This involves all the apparatus that were used including the ICP-OES and microwave.

\subsubsection{Microwave}

Microwave digestion was done with a pressurized microwave (MARS 6, CEM) equipped with rotor that holds the vessels.

\subsubsection{Inductively Coupled Plasma- Optical Emission Spectroscopy (ICP-OES)}

Analysis of $\mathrm{Cd}, \mathrm{Cr}, \mathrm{Cu}, \mathrm{Zn}$ and $\mathrm{Pb}$ was done using ICP-OES (Perkin Elmer, Optima 5300DV). The elements wavelengths were optimised in the instrument before calibration. These were Cd: 214.440; $\mathrm{Cr}$ : 283.563, Cu: 327.393, Pb: 220.353, Zn: $213.857 \mathrm{~nm}$. Blanks and standards were used for calibration at the accepted correlation coefficient of greater than 0.995 .

\subsection{Sampling and procedure}

Water samples were collected in pre cleaned polyethylene bottles and preserved with $0.5 \mathrm{~mL}$ concentrated HNO3 on site and put in an ice box (Singh et al., 2005). They were refrigerated at $4^{\circ} \mathrm{C}$ before analysis in the laboratory. Surface sediment samples were collected using a plastic scoop and placed directly into plastic bags and air dried.

Water samples were filtered through a $0.45 \mu \mathrm{m}$ filter and analysed using Perkin Elmer ICP-OES. The dried sediment samples were ground using a pestle and mortar and sieved to $90 \mu \mathrm{m}$ and stored in plastic bags before analysis.

The sediment samples and certified reference material were oven dried overnight at $60{ }^{\circ} \mathrm{C}$ to ensure complete dryness. Approximately $0.5 \mathrm{~g}$ of the sample was weighed into a microwave vessel. The samples were acid digested in the vessels using $10 \mathrm{~mL}$ aqua regia 1:3 ( $\mathrm{HNO}$ : $\mathrm{HCl}$ ) using MARSXpress, CEM microwave.

The microwave was set to ramp to $180{ }^{\circ} \mathrm{C}$ for 15 minutes, hold at $180{ }^{\circ} \mathrm{C}$ for 15 minutes and cool for 15 minutes. The vessels were allowed to cool at room temperature to further reduce the pressure as part of the operation procedure to avoid leaking of the solution. Elemental analysis was made using ICP-OES. Statistical analysis was done using Microsoft Excel and Statistical Package for Social Scientists (SPSS) version 18.

\section{Results and discussion}

Results show the certified reference material recoveries and total metals in water and sediments.

\subsection{Quality assurance}

Certified reference materials were used for quality assurance. Table 1 shows experimental values as compared to certified values and the relative percentage recovery. Percentage recovery of metals between $80-120 \%$ are generally acceptable (FAO, 2011; USEPA, 2012a).

Table 1: Experimental values for concentration of metals as compared to certified values and percentage recoveries $n$

\begin{tabular}{|l|l|l|l|}
\hline Analyte name & $\begin{array}{l}\text { Experimental } \\
\text { concentration }(\mathbf{m g} \\
\text { kg-1) }\end{array}$ & $\begin{array}{l}\text { Certified value }(\mathbf{m g} \\
\mathbf{k g - 1})\end{array}$ & \% Recovery \\
\hline $\mathrm{Cd}$ & $0.975+0.12$ & $0.817+0.011$ & $119+14$ \\
\hline
\end{tabular}




\begin{tabular}{|l|l|l|l|}
\hline $\mathrm{Cr}$ & $281+5.0$ & $352+22$ & $80+1.5$ \\
\hline $\mathrm{Cu}$ & $107.7+1.1$ & $117.7+5.6$ & $92+0.96$ \\
\hline $\mathrm{Pb}$ & $107+3.5$ & $132.8+1.1$ & $81+2.6$ \\
\hline $\mathrm{Zn}$ & $449.7+11$ & $485.3+4.2$ & $93+2.2$ \\
\hline
\end{tabular}

$n$ (number of replicate analysis of the certified reference material) $=3$

The percentage recoveries are within the accepted range hence it validates the procedure for the metal analysis (Table 1).

\subsection{Total metals in wetlands}

Water typically has lower metal concentrations compared to sediments. This is due to constant mixing and flow (Mutia et al., 2012). This trend was also observed in the university wetlands, wherein the concentration of metals are lower than $0.100 \mathrm{mg} \mathrm{L}-1$ with $\mathrm{Cd}, \mathrm{Cr}, \mathrm{Cu}$ and $\mathrm{Zn}$ below the detection limit at some of the sites. The ranges for these metals are $\mathrm{Cd}$ (1.0-6.0), $\mathrm{Cu}$ (1.0-11.0), $\mathrm{Cr}(0.3-82.7), \mathrm{Zn}(2.7-65.0)$ and $\mathrm{Pb}(0.3-16.0)$ all in $\mu \mathrm{g}$ L-1.

\subsubsection{Cadmium, Chromium and Lead}

These three metals showed the highest concentrations during winter. Thus, winter as the dry season usually has the highest concentration of metals because there are no dilutions from rain (Lokeshwari et al., 2006). Autumn is also classified as a dry season but unlike winter dry season; there were rains during the sampling period. The SABS value from DWAF for Cd is $150 \mu \mathrm{g} \mathrm{L}-1$ and from EPA is (8.8 $\mu \mathrm{g} \mathrm{L}-1)$ (DWAF, 1996b; FDEP, 2013). All the sites for Cd are below SABS limit indicating it is in the permissible level. Though Cd has a lower concentration, it is still a toxic element and not essential to aquatic life (Fianko et al., 2007). Autumn and summer samples showed fluctuations with sites $\mathrm{A}, \mathrm{C}$ and $\mathrm{H}$ in autumn having $\mathrm{Cd}$ below the detection limit. Generally no specific spatial trend was observed in winter and spring concentrations especially at the upper catchment.

The SABS accepted value for $\mathrm{Cr}$ is $7.0 \mu \mathrm{g} \mathrm{L}-1$ and the respective EPA value is (50.0 $\mu \mathrm{g} \mathrm{L}-1)$ (DWAF, 1996b; FDEP, 2013). All sites exceed the SABS limit in winter but other seasons are below the standard (Figure 2). Compared to the EPA standard, autumn, spring and summer are below the limit and sites B, D, E and G also exceed this limit. Mutia et al (2012) reported that high concentration of metals in surface water indicates that the pollution is recent, as the water exhibit high mobility (Mutia et al., 2012). Thus high winter values indicate that there was a recent input of $\mathrm{Cr}$ into the river at the start of industries. The industries most likely responsible for the elevated $\mathrm{Cr}$ concentration may be chemical and textile.

$\mathrm{Pb}$ in $\mathrm{B}$ (autumn) was below the detection limit, all sites for all seasons are exceeding the SABS limit and also exceed the EPA limit in the winter season. The SABS limit is $0.2 \mu \mathrm{g} \mathrm{L}-1$ while the EPA is $(8.5 \mu \mathrm{g} \mathrm{L}-1)$ (DWAF, 1996b; FDEP, 2013).Seasonal variation shows winter having the highest concentration in all sites except $\mathrm{A}$ and $\mathrm{H}$ in summer.

\subsubsection{Copper and Zinc}

$\mathrm{Cu}$ and $\mathrm{Zn}$ showed distinct seasonal fluctuations. Wet season had the highest concentration among other seasons. Sites exceeded the SABS Cu limit of (0.3 $\mu \mathrm{g}$ L-1) (DWAF, 1996b) except for A, B, C and H in wet season which had concentrations below the detection limit. All sites were below the EPA limit which is (3.7 $\mu \mathrm{g} \mathrm{L-1})$ (FDEP, 2013).

Zn does not follow any seasonal or spatial trend, but its concentrations compared to the SABS limit all sites exceeded the recommended limits except sites A and B (dry season) which were below detection limit. Figure 2 shows concentration of $\mathrm{Zn}$ in all sites compared to the SABS values. Comparing the concentration of $\mathrm{Zn}$ in samples to the standards of $2.0 \mu \mathrm{g} \mathrm{L}-1$ and $86 \mu \mathrm{g} \mathrm{L}-1$ for SABS and EPA respectively, all sites had concentration below the SABS and EPA standards (DWAF, 1996b; FDEP, 2013).

Most sites are above the stipulated limit, thus the ecosystem of the university of Lagos wetland may have been negatively affected by the various activities around it. These metals may be from natural sources especially in the upper catchment immediately from industries in the lower catchment. The waste 
management plant receives waste-water from households and industries which is treated and disposed into the lagoon. The input of pollutants from the waste management brings a change to the dynamics of the metals in the lagoon. The water discharged is not free from pollutants, as the concentrations in those areas are very high. This is observed in the three preceding sites; thus it explains the increase in concentration of metals just after the connection with the waste management. Moreover, in autumn and winter there was construction at $\mathrm{H}$ and it is observed that there is high concentration of $\mathrm{Pb}, \mathrm{Cu}$ and $\mathrm{Zn}$ in that area for dry season.

Table 2: Average total concentrations for wetlands data

\begin{tabular}{|c|c|c|c|c|}
\hline $\begin{array}{l}\text { Si } \\
\text { te } \\
\text { co } \\
\text { de }\end{array}$ & Seasons & Wet & & dry \\
\hline $\mathbf{A}$ & $\mathrm{Cd}$ & $<\mathrm{DL}$ & 0.0027 & 0.0020 \\
\hline \multicolumn{2}{|c|}{$\mathrm{Cr}$} & $<\mathrm{DL}$ & $<\mathrm{DL}$ & 0.0003 \\
\hline \multicolumn{2}{|l|}{$\mathrm{Cu}$} & $<\mathrm{DL}$ & 0.0087 & 0.0097 \\
\hline \multicolumn{2}{|l|}{$\mathrm{Mn}$} & 0.0327 & 0.1257 & 0.1777 \\
\hline \multicolumn{2}{|l|}{$\mathrm{Pb}$} & 0.001 & 0.0033 & 0.0083 \\
\hline \multicolumn{2}{|l|}{$\mathrm{Zn}$} & $<\mathrm{DL}$ & 0.0237 & 0.0157 \\
\hline B & $\mathrm{Cd}$ & 0.0020 & 0.0020 & 0.0020 \\
\hline \multicolumn{2}{|l|}{$\mathrm{Cr}$} & $<\mathrm{DL}$ & 0.0057 & $<\mathrm{DL}$ \\
\hline \multicolumn{2}{|l|}{$\mathrm{Cu}$} & 0.0090 & $<\mathrm{DL}$ & 0.0020 \\
\hline \multicolumn{2}{|l|}{$\mathrm{Mn}$} & 0.0930 & 0.0380 & 0.1996 \\
\hline \multicolumn{2}{|l|}{$\mathrm{Pb}$} & $<\mathrm{DL}$ & 0.0010 & 0.0023 \\
\hline \multicolumn{2}{|l|}{$\mathrm{Zn}$} & 0.0290 & 0.0173 & 0.0027 \\
\hline $\mathbf{C}$ & $\mathrm{Cd}$ & $<\mathrm{DL}$ & 0.0013 & 0.0013 \\
\hline \multicolumn{2}{|c|}{$\mathrm{Cr}$} & $<\mathrm{DL}$ & 0.0040 & $<\mathrm{DL}$ \\
\hline \multicolumn{2}{|l|}{$\mathrm{Cu}$} & 0.0007 & 0.0010 & 0.0010 \\
\hline \multicolumn{2}{|l|}{$\mathrm{Mn}$} & 0.0867 & 0.0537 & 0.0346 \\
\hline \multicolumn{2}{|l|}{$\mathrm{Pb}$} & 0.0003 & 0.0003 & 0.0010 \\
\hline \multicolumn{2}{|l|}{$\mathrm{Zn}$} & 0.0123 & 0.0177 & $<\mathrm{DL}$ \\
\hline D & $\mathrm{Cd}$ & 0.002 & 0.0010 & 0.0017 \\
\hline \multicolumn{2}{|c|}{$\mathrm{Cr}$} & 0.001 & 0.0040 & $<\mathrm{DL}$ \\
\hline \multicolumn{2}{|l|}{$\mathrm{Cu}$} & 0.0050 & 0.0067 & 0.0010 \\
\hline \multicolumn{2}{|l|}{$\mathrm{Mn}$} & 0.0830 & 0.0710 & 0.0463 \\
\hline \multicolumn{2}{|l|}{$\mathrm{Pb}$} & 0.0010 & 0.0003 & 0.0007 \\
\hline \multicolumn{2}{|l|}{$\mathrm{Zn}$} & 0.0130 & 0.0290 & 0.0067 \\
\hline $\mathbf{E}$ & $\mathrm{Cd}$ & 0.002 & 0.0010 & 0.0017 \\
\hline \multicolumn{2}{|c|}{$\mathrm{Cr}$} & 0.002 & 0.0033 & $<\mathrm{DL}$ \\
\hline \multicolumn{2}{|l|}{$\mathrm{Cu}$} & 0.0120 & 0.0013 & 0.0013 \\
\hline \multicolumn{2}{|l|}{$\mathrm{Mn}$} & 0.1800 & 0.0766 & 0.0866 \\
\hline \multicolumn{2}{|l|}{$\mathrm{Pb}$} & 0.0050 & 0.0030 & 0.0017 \\
\hline \multicolumn{2}{|l|}{$\mathrm{Zn}$} & 0.0060 & 0.0277 & 0.0077 \\
\hline $\mathbf{F}$ & $\mathrm{Cd}$ & 0.0010 & 0.0020 & 0.0013 \\
\hline \multicolumn{2}{|c|}{$\mathrm{Cr}$} & 0.0020 & 0.0043 & 0.0033 \\
\hline $\mathrm{Cu}$ & & 0.0050 & 0.0307 & 0.0110 \\
\hline $\mathrm{Mn}$ & & 0.1880 & 0.1517 & 0.1033 \\
\hline $\mathrm{Pb}$ & & $<\mathrm{DL}$ & 0.0063 & 0.0017 \\
\hline $\mathrm{Zn}$ & & 0.0150 & 0.1953 & 0.0596 \\
\hline G & $\mathrm{Cd}$ & 0.0020 & 0.0020 & 0.0017 \\
\hline $\mathrm{Cr}$ & & 0.0030 & 0.0010 & 0.0003 \\
\hline
\end{tabular}




\begin{tabular}{|l|l|l|l|}
\hline $\mathrm{Cu}$ & 0.0070 & 0.0053 & 0.0030 \\
\hline $\mathrm{Mn}$ & 0.2320 & 0.1030 & 0.1030 \\
\hline $\mathrm{Pb}$ & 0.0030 & 0.0030 & 0.0020 \\
\hline $\mathrm{Zn}$ & 0.0170 & 0.3130 & 0.0103 \\
\hline $\mathbf{H}$ & 0.0020 & 0.0017 & 0.0020 \\
\hline & $\mathrm{Cd}$ & & \\
\hline $\mathrm{Cr}$ & 0.0030 & 0.0013 & 0.0030 \\
\hline $\mathrm{Cu}$ & 0.0080 & 0.0063 & 0.0110 \\
\hline $\mathrm{Mn}$ & 0.2330 & 0.1050 & 0.1663 \\
\hline $\mathrm{Pb}$ & 0.0040 & 0.0056 & 0.0160 \\
\hline $\mathrm{Zn}$ & 0.0150 & 0.0313 & 0.0290 \\
\hline
\end{tabular}

$<$ DL: Below Detection Limit

\subsection{Total metals in sediments}

Total metals refer to individual concentrations of metals in the sediments and their measurement plays an important role in the environment. They indicate the level of pollution by providing individual concentrations at different sampling points (Divvela, 2010). High concentrations of metals accumulate in the sediments, and later be dispersed into the environment. Therefore, this study investigates the concentrations $\mathrm{Cd}, \mathrm{Cr}, \mathrm{Cu}, \mathrm{Pb}$ and $\mathrm{Zn}$ to determine toxicity and seasonal variability. Statistical analysis for variability of sediment was done using one-way ANOVA.

The significant differences were between the dry season and the wet season hence the data presented will show the lowest amount of rainfall received, representing the dry season and the highest rainfall will represent the wet season. After the wet season, the turbidity decreases due to reduced mixing from rainfall; hence metal concentrations decrease in the dry season as metals have been washed away. The spatial distribution of each of the metals shows the trend at which the metal was following from the upper catchment till the lower catchment. There is no Nigeria sediment guideline therefore the EPA standard was used to determine if metal concentrations were within the acceptable limit (Gordon et al., 2010).

\subsubsection{Cadmium}

There were high values of $\mathrm{Cd}$ in the wet season hence there is higher input in the wet season than in the dry season. Wet season showed Cd concentration below the detection limit $0.1 \mu \mathrm{g} \mathrm{L}-1$ (PerkinElmer, 2008) in D, E, F and G. Low concentrations were expected during dry season because of lower rainfall. Table 3 shows a comparison of sites to the EPA guideline value of $0.676 \mathrm{mg} \mathrm{kg}-1$; all concentrations obtained for $\mathrm{Cd}$ in dry season exceeded the limit. Sites A, C, F and H in wet season also exceeded the EPA limit

Table 3: Cd concentration ( $\mathrm{mg} \mathrm{kg-1}$ ) in sediments compared to the EPA guideline value, $n=3$

\begin{tabular}{|c|c|c|c|c|c|c|c|c|}
\hline & A & B & $\mathbf{C}$ & $\mathbf{E}$ & $\mathbf{F}$ & $\mathbf{G}$ & $\mathbf{H}$ & \\
\hline Dry & $\begin{array}{l}133.84 \\
( \pm 0.92)\end{array}$ & $\begin{array}{l}166.40+ \\
0.37\end{array}$ & $\begin{array}{l}117.34+ \\
1.4\end{array}$ & $\begin{array}{l}199.22+ \\
0.41\end{array}$ & $\begin{array}{l}207.91+ \\
1.8\end{array}$ & $\begin{array}{l}351.36+ \\
0.79\end{array}$ & $\begin{array}{l}156.10+ \\
1.3\end{array}$ & $\begin{array}{l}191.5 \\
7+ \\
1.1\end{array}$ \\
\hline Wet & $\begin{array}{l}* 0.23+ \\
0.42\end{array}$ & $\begin{array}{l}1.98+ \\
0.32\end{array}$ & $5.23+1.7$ & $* 0.00$ & $* 0.00$ & $* 0.00$ & $* 0.00$ & $\begin{array}{l}* 0.46 \\
+ \\
0.17\end{array}$ \\
\hline EPA & 0.676 & 0.676 & 0.676 & 0.676 & 0.676 & 0.676 & 0.676 & 0.676 \\
\hline
\end{tabular}

(Standard deviation), *Below EPA limit

Cd concentrations showed fluctuations at the upper catchment of the wetland, especially in the wet season, with an increase at the settlement to industrial zone. The wet season showed an increased input of $\mathrm{Cd}$ at the industries; $\mathrm{E}$ and $\mathrm{F}$ had an increase in concentration. The increase in concentration of $\mathrm{Cd}$ at $\mathrm{F}$ reflected that 
inputs of $\mathrm{Cd}$ are likely to be from the waste management plant or domestic waste entering from the informal settlement. Concentration of $\mathrm{Cd}$ may be due to concentration effects from inputs of discharge from industries, landfills and use of fertilizers. Use of phosphate fertilizer in agriculture may pollute the river as Cd binds into organic matter, phosphate, sulphate, hydroxide and carbonate (Fianko et al., 2007).

It is stated that $\mathrm{Cd}$ may be adsorbed into sediments immediately or be transported in aqueous solution to a distance of $50 \mathrm{~km}$ and later settle back into the sediments (Friberg et al., 1992). It can be assumed that Cd from the upper sites settled in the estuarine site as the water is almost stagnant. The wetland may be impacted by industries along it such as battery, steel and paint industries which are sources of $\mathrm{Cd}$. The high concentration of $\mathrm{Cd}$ accumulated in sediments to the aquatic life as $\mathrm{Cd}$ is a toxic metal. The possible impacts of this high $\mathrm{Cd}$ concentration on humans are brain damage and pains in the bones (Fatoki et al., 2002). These happen when $\mathrm{Cd}$ is released from sediments in dissolved form into the wetland and taken up by fish and other aquatic animals which are then consumed by humans.

\subsubsection{Lead}

Spatial distribution shows the industrial sites having lower amount of $\mathrm{Pb}$ as compared to the upper catchment. This suggests that the pollution in that area was anthropogenic. It may be from chemical weathering during high temperatures in the wet season releasing Cd (Dekov, Komy, Araújo, et al., 1997). Compared to the EPA limit $30.2 \mathrm{mg} \mathrm{kg-1}$; spring and summer had high concentration of $\mathrm{Pb}$ which exceeded the EPA limit, whereas in autumn and winter, concentrations were low and were below the limit as shown in Figure 3. The concentration of $\mathrm{Pb}$ in $\mathrm{A}, \mathrm{B}, \mathrm{C}, \mathrm{D}, \mathrm{E}$ and $\mathrm{F}$ in autumn and winter were below the EPA stipulated limit.

The spatial distribution for $\mathrm{Pb}$ in the wet season shows high concentrations in $\mathrm{A}$, then fluctuation in $\mathrm{D}$. Sources of $\mathrm{Pb}$ along wetlands may include paint and battery manufacturing present along the lagoon at the start of industries (Agarwal, 2009). Agricultural activities may also contribute to the concentration of $\mathrm{Pb}$ at the start of industries as $\mathrm{Pb}$ is found in some fertilizers (Maroulis et al., 2007; McLaughlin et al., 1996). The minor increase in $\mathrm{Pb}$ concentration in $\mathrm{F}$ may be due to the waste management plant or the informal settlement located near the area. The effluent discharge from the waste plant and the runoff from the settlement may increase the concentration of $\mathrm{Pb}$ (Fatoki et al., 2002).

Closer to the informal settlement there is litter composed of cans and other metal materials which rust and may have added to the amount of contamination. When deposited in solid form such as ash, few $\mathrm{Pb}$ compounds readily dissolve in water but will be precipitated as solid into sediments. Generally the industrial site has lower concentrations and only an immediate increase at H. Wright et.al. (1999) explained this increase that high concentrations of metals in estuaries are caused by the feeding lagoon and direct discharges (Wright et al., 1999). It could therefore be expected that $\mathrm{Pb}$ from the upper catchments was trapped in the estuary and accumulated in the sediments, or may be as a result of construction works.

Table 4: Average total concentrations for sediment data

\begin{tabular}{|l|l|l|l|l|l|}
\hline $\begin{array}{l}\text { Site } \\
\text { cod } \\
\text { e }\end{array}$ & Seasons & wet & Wet & Dry & Dry \\
\hline
\end{tabular}




\begin{tabular}{|c|c|c|c|c|c|}
\hline $\mathbf{A}$ & $\mathrm{Cd}$ & 1.32 & 0.23 & 197.39 & 133.84 \\
\hline \multicolumn{2}{|l|}{$\mathrm{Pb}$} & 12.87 & 12.13 & 536.75 & 601.70 \\
\hline \multicolumn{2}{|c|}{$\mathrm{Cu}$} & 13.47 & 16.13 & 84.72 & 106.02 \\
\hline \multicolumn{2}{|c|}{$\mathrm{Cr}$} & 57.75 & 51.75 & 67.07 & 94.16 \\
\hline \multicolumn{2}{|c|}{$\mathrm{Zn}$} & 62.25 & 81.95 & 104.05 & 89.75 \\
\hline \multicolumn{2}{|c|}{$\mathrm{Mn}$} & 537.39 & 632.76 & 80.83 & 89.87 \\
\hline B & $\mathrm{Cd}$ & 0.07 & 1.98 & 126.00 & 166.40 \\
\hline \multicolumn{2}{|c|}{$\mathrm{Pb}$} & 19.62 & 20.88 & 430.79 & 205.60 \\
\hline \multicolumn{2}{|c|}{$\mathrm{Cu}$} & 22.87 & 27.11 & 82.54 & 118.01 \\
\hline \multicolumn{2}{|c|}{$\mathrm{Cr}$} & 72.46 & 83.50 & 54.04 & 48.93 \\
\hline \multicolumn{2}{|c|}{$\mathrm{Zn}$} & 109.95 & 95.75 & 61.94 & 60.86 \\
\hline \multicolumn{2}{|c|}{$\mathrm{Mn}$} & 5012.82 & 9822.15 & 46.70 & 62.45 \\
\hline $\mathbf{C}$ & $\mathrm{Cd}$ & 1.25 & 5.23 & 164.67 & 117.34 \\
\hline \multicolumn{2}{|c|}{$\mathrm{Pb}$} & 21.07 & 27.07 & 528.37 & 525.83 \\
\hline \multicolumn{2}{|c|}{$\mathrm{Cu}$} & 33.03 & 11.86 & 62.22 & 114.54 \\
\hline \multicolumn{2}{|c|}{$\mathrm{Cr}$} & 86.27 & 135.06 & 45.92 & 28.61 \\
\hline \multicolumn{2}{|c|}{$\mathrm{Zn}$} & 80.57 & 73.47 & 82.90 & 29.51 \\
\hline \multicolumn{2}{|c|}{$\mathrm{Mn}$} & 1040.02 & 2189.52 & 45.50 & 56.53 \\
\hline D & $\mathrm{Cd}$ & 0.18 & $<\mathrm{DL}$ & 250.79 & 199.22 \\
\hline \multicolumn{2}{|c|}{$\mathrm{Pb}$} & 15.28 & 22.51 & 304.21 & 95.39 \\
\hline \multicolumn{2}{|c|}{$\mathrm{Cu}$} & 21.00 & 24.92 & 165.71 & 105.81 \\
\hline \multicolumn{2}{|c|}{$\mathrm{Cr}$} & 57.39 & 78.95 & 78.14 & 88.50 \\
\hline \multicolumn{2}{|c|}{$\mathrm{Zn}$} & 84.41 & 77.96 & 80.43 & 92.41 \\
\hline \multicolumn{2}{|c|}{$\mathrm{Mn}$} & 474.74 & 687.58 & 72.83 & 62.87 \\
\hline $\mathbf{E}$ & $\mathrm{Cd}$ & 0.20 & $<\mathrm{DL}$ & 264.46 & 207.91 \\
\hline \multicolumn{2}{|c|}{$\mathrm{Pb}$} & 55.04 & 28.60 & 225.54 & 256.21 \\
\hline \multicolumn{2}{|c|}{$\mathrm{Cu}$} & 37.55 & 21.75 & 154.26 & 67.99 \\
\hline $\mathrm{Cr}$ & & 81.94 & 60.86 & 91.99 & 63.62 \\
\hline $\mathrm{Zn}$ & & 176.50 & 103.89 & 96.90 & 81.31 \\
\hline $\mathrm{Mn}$ & & 499.54 & 497.57 & 81.11 & 64.18 \\
\hline $\mathbf{F}$ & $\mathrm{Cd}$ & 0.73 & 0.99 & 205.18 & 151.81 \\
\hline $\mathrm{Pb}$ & & 136.13 & 53.82 & 186.02 & 144.73 \\
\hline $\mathrm{Cu}$ & & 133.49 & 81.21 & 128.53 & 119.99 \\
\hline $\mathrm{Cr}$ & & 126.35 & 111.94 & 98.14 & 102.86 \\
\hline $\mathrm{Zn}$ & & 602.12 & 246.20 & 57.98 & 103.25 \\
\hline $\mathrm{Mn}$ & & 737.18 & 1052.19 & 48.60 & 85.70 \\
\hline $\mathbf{G}$ & $\mathrm{Cd}$ & 0.13 & $<\mathrm{DL}$ & 207.90 & 351.36 \\
\hline $\mathrm{Pb}$ & & 65.88 & 28.81 & 211.16 & 266.26 \\
\hline $\mathrm{Cu}$ & & 80.88 & 132.99 & 123.95 & 123.01 \\
\hline $\mathrm{Cr}$ & & 127.45 & 55.08 & 82.71 & 116.10 \\
\hline $\mathrm{Zn}$ & & 420.65 & 469.92 & 59.20 & 146.33 \\
\hline $\mathrm{Mn}$ & & 649.32 & 284.25 & 54.80 & 117.70 \\
\hline $\mathbf{H}$ & $\mathrm{Cd}$ & $<\mathrm{DL}$ & $<\mathrm{DL}$ & 211.95 & 156.10 \\
\hline $\mathrm{Pb}$ & & 51.15 & 32.98 & 174.83 & 212.95 \\
\hline $\mathrm{Cu}$ & & 65.97 & 118.92 & 164.00 & 168.47 \\
\hline $\mathrm{Cr}$ & & 98.83 & 52.17 & 105.36 & 122.31 \\
\hline $\mathrm{Zn}$ & & 262.63 & 339.37 & 81.24 & 131.85 \\
\hline $\mathrm{Mn}$ & & 472.56 & 389.46 & 82.09 & 107.57 \\
\hline
\end{tabular}

$<$ L: Below Detection Limit

\section{Conclusion}

The concentration of $\mathrm{Cd}, \mathrm{Cr}, \mathrm{Cu}, \mathrm{Pb}$ and $\mathrm{Zn}$ in wetlands and sediments, seasonal variations and their distribution along the Lagoon has been found. Concentrations were compared to the SABS and EPA wetland and sediment quality guidelines. Waetland data showed $\mathrm{Cr}, \mathrm{Cu}, \mathrm{Zn}$ and $\mathrm{Pd}$ above the stipulated $\mathrm{SABS}$ limit while for sediments $\mathrm{Cd}, \mathrm{Cr}, \mathrm{Cu}, \mathrm{Pb}$ and $\mathrm{Zn}$ were above the EPA limit. In the wet season $\mathrm{Cd}$ in 
water was below the SABS limit and above for sediments. Based on this, use of water directly from the lagoon may pose health problems like kidney disease, bone disease, brain damage and other illnesses (Fatoki et al., 2002).

The results showed there was a significant difference in concentration of metals in sediments between the dry seasons and the wet seasons. The study shows a variation in the amounts of metals at different sampling points due to varying types of activities along the lagoon. The spatial distribution showed an increase in concentration of $\mathrm{Cd}, \mathrm{Cr}, \mathrm{Cu}, \mathrm{Pb}$ and $\mathrm{Zn}$ at the start of industries moving down to the end of industries, with $\mathrm{Cd}, \mathrm{Cr}$ and $\mathrm{Pb}$ mostly at the estuarine site; ES. Construction was conducted near site $\mathrm{H}$ during these seasons which ceased before dry season hence detectable in the wet seasons, this may have been due to dredging of sediments from the land. The upper catchment which is A to $\mathrm{C}$ shows an increase in concentration of $\mathrm{Cd}$, $\mathrm{Cr}, \mathrm{Cu}$ and $\mathrm{Pb}$ in the dry season but a decrease in the wet season. Unlike other metals; $\mathrm{Zn}$ showed a decrease from $\mathrm{A}$ to $\mathrm{C}$ but only in the wet season with fluctuations in the dry seasons. Most of the metals increase in concentration at the waste management facility and decrease down the preceding sites. Sediment samples particularly those taken during the wet season showed the highest levels of contamination while the water showed a peak in contamination during the dry season. The highest contamination is in the residential site. Generally the river shows that it is in poor health as most of the metals in water and sediment are exceeding the SABS and EPA limits respectively. There is a need for increased environmental monitoring along the University of Lagos wetlands.

\section{Acknowledgement}

This research was made possible by the University of Lagos and Department of Cell biology and Genetics.

\section{Conflict of interest}

The authors declare no competing interest

\section{References}

Agarwal S.K. (2009). Heavy metal pollution Vol. 4. (pp. 37-71). Retrieved from http://books.google.co.za/books?hl=en\&lr=\&id=nmputkzWWkkC\&oi=fnd\&pg=PR5\&dq=Heavy+metal+ pollution+by+Agarwal+S+K\&ots=SdHT21I2dY\&sig=S7U_BhEnnbDnDrULAQPoQdDrWrk\#v=onepag e\&q=Heavy\%20metal\%20pollution\%20by\%20Agarwal\%20S\%20K\&f=false

Alagarsamy, R. (2006). Distribution and seasonal variation of trace metals in surface sediments of the Mandovi estuary, west coast of India. Estuarine, Coastal and Shelf Science, 67(1-2), 333-339.

Barratt, G. J., Combrink, J.,. (2002). An assessment of the degree of mercury (Hg) bio-transformation in two river systems following discharges from a mercury recovery plant. Technikon Natal, Durban, South Africa.

Coetzee., Du Preez, H. H., \& Van Vuren, J. H. J. (2002). Metal concentrations in Clarias gariepinus and Labeo umbratus from the Olifants and Klein Olifants River, Mpumalanga, South Africa: Zinc, copper, manganese, lead, chromium, nickel, aluminium and iron. Water SA, 28(4), 433-448.

Dekov V. M., Komy Z., Araújo F., Van Put A., \& Van Grieken R. (1997). Chemical composition of sediments, suspended matter, river water and ground water of the Nile (Aswan-Sohag traverse). Science of the total environment, 201(3), 195-210.

Dickens, C. W. S., \& Graham, P. M. (1998). Biomonitoring for effective management of wastewater discharges and the health of the river environment. Aquatic ecosystem health and management, 1(2), 199217.

Divvela. (2010). Sequential exraction procedure, Lab Science News.

DWAF. (1996b). South African water quality guidelines Aquatic ecosystems. Pretoria: Department of Water Affairs and Forestry.

FAO. ( 2011). Quality assurance for animal feed analysis laboratories FAO Animal Production and Health Manual (Vol. 14). Rome. 
Farkas, A., Erratico, C., \& Vigano, L. (2007). Assessment of the environmental significance of heavy metal pollution in surficial sediments of the River Po. Chemosphere, 68(4), 761-768.

Fatoki, O., Lujiza, N., \& Ogunfowokan, A. (2002). Trace metal pollution in Umtata River. Water SA, 28(2), 183-190.

FDEP. (1994). Numerical Sediment Quality Assessment Guidelines for Florida Coastal Waters. USA: USEPA.

FDEP. (2013). Surface water quality standards. In USEPA (Ed.), Sections of Florida Administrative code addressing water quality standards. USA.

Fianko, J., Osae, S., Adomako, D., Adotey, D., \& Serfor-Armah, Y. (2007). Assessment of heavy metal pollution of the Iture Estuary in the central region of Ghana. Environmental monitoring and assessment, 131(1-3), 467-473.

Friberg L., Elinder C. G., \& Kjellstrim T. (1992). International programme on chemical safety. In W. H. Organisation (Ed.), Environmental health criteria for cadmium. New Zealand: Karolinska Institute, Sweden and University of Auckland, New Zealand.

Gordon, A. K., \& Muller, W. J. (2010). Developing sediment quality guidelines for South Africa. PHASE 1: Identification of international best practice and applications for South Africa to develop a research and implementation framework Retrieved 09/10/2013, 2013, from http://www.wrc.org.za/Pages/DisplayItem.aspx?ItemID=8754\&FromURL=\%2FPages\%2FAllKH.aspx\% $3 \mathrm{~F}$

Kamau, J. N., Gachanja, A., Ngila, C., Kazungu, J. M., \& Zhai, M. (2008). Anthropogenic and seasonal influences on the dynamics of selected heavy metals in Lake Naivasha, Kenya. Lakes \& Reservoirs: Research \& Management, 13(2), 145-154.

Kankılıç, G. B., Tüzün, İ., \& Kadığlu, Y. K. (2013). Assessment of heavy metal levels in sediment samples of Kapulukaya Dam Lake (Kirikkale) and lower catchment area. Environmental monitoring and assessment, 1-12.

Lokeshwari, H., \& Chandrappa, G. (2006). Impact of heavy metal contamination of Bellandur Lake on soil and cultivated vegetation. Current science, 91(5), 622-627.

Maroulis, M., Economou, A., \& Voulgaropoulos, A. (2007). Determination of $\mathrm{Cd}$ and $\mathrm{Pb}$ in phosphorites and phosphate fertilizers by means of a portable voltammetric analyzer based on "Virtual Instrumentation". Electroanalysis, 19(19-20), 2149-2154.

McLaughlin, M. J., Tiller, K., Naidu, R., \& Stevens, D. (1996). Review: the behaviour and environmental impact of contaminants in fertilizers. Soil Research, 34(1), 1-54.

Mondol, M., Chamon, A., Faiz, B., \& Elahi, S. (2011). Seasonal variation of heavy metal concentrations in Water and plant samples around Tejgaon industrial Area of Bangladesh. Journal of Bangladesh Academy of Sciences, 35(1), 19-41.

Mutia, T., Virani, M., Moturi, W., Muyela, B., Mavura, W., \& Lalah, J. (2012). Copper, lead and cadmium concentrations in surface water, sediment and fish, C. Carpio, samples from Lake Naivasha: effect of recent anthropogenic activities. Environmental Earth Sciences, 67(4), 1121-1130.

Okonkwo, J. O., \& Mothiba, M. (2004). Physico-chemical characteristics and pollution levels of heavy metals in the rivers in Thohoyandou, South Africa. Journal of Hydrology, 308(1-4), 122-127.

PerkinElmer. (2008). World leader in AA, ICP-OES and ICP-MS 2011. Retrieved 26/08/2013, 2013, from www.perkinelmer.com/PDFs/Downloads/BRO_WorldleaderAAICPMSICPMS.pdf

Ramjatan, A., Ahmed, F., Hodgson, K., Simpson, D., \& Quinn, N. (2000). The Potential Impacts of Water Fluoridation: A Case Study of the Umgeni Water Operational Area, KwaZulu-Natal.

Saleh Tabari., Seyed Soheil Saeedi Saravi., Gholamali A Bandany., Atena Dehghan., \& Mohammad Shokrzadeh. (2010). Heavy metals ( $\mathrm{Zn}, \mathrm{Pb}, \mathrm{Cd}$ and $\mathrm{Cr}$ ) in fish, water and sediments sampled from Southern Caspian Sea, Iran. Toxicology and Industrial Health, 26(10), 649-656.

Sherman, H. M. (1998). The assessment of groundwater quality in rural communities : two case studies from KwaZulu-Natal. Masters, University of KwaZulu-Natal, Durban, South Africa. 
Singh, K. P., Mohan, D., Singh, V. K., \& Malik, A. (2005). Studies on distribution and fractionation of heavy metals in Gomti river sediments - a tributary of the Ganges, India. Journal of Hydrology, 312(1-4), 14-27.

Tsai, L.-j., Yu, K.-c., \& Ho, S.-T. (2007). Cadmium distribution in sediment profiles of the six main rivers in southern Taiwan. Journal of Hazardous Materials, 148(3), 630-639.

Udaysankar Banerjee, \& Gupta, S. (2012). Source and distribution of Lead, Cadmium, Iron and Manganese in the river Damodar near Asansol Industrial Area, West Bengal, India. International journal of Environmental Sciences, 2(3).

UmgeniWater. (2013). How people affect our water quality. Water for growth and sustainable development Retrieved 17/10/2013, from http://www.umgeni.co.za/water_education/wpwq.asp

USEPA. (2001). Methods for collection, storage and manipulation of sediments for chemical and toxicological analyses: technical manual. Washington: United Sates Environmental Protection Agency.

USEPA. (2007). Microwave assisted acid digestion of sediments, sludges, soils and oils Method 3051A. USA: Environmental Protection Agency.

USEPA. (2012). Analytical control facility. In U. S. F. a. w. service (Ed.), Division of environmental quality. Shepherstown, West Virginia: U.S. Fish and wildlife.

Wright, P., \& Mason, C. F. (1999). Spatial and seasonal variation in heavy metals in the sediments and biota of two adjacent estuaries, the Orwell and the Stour, in eastern England. Science of the total environment, 226(2-3), 139-156.

Ye, F., Huang, X., Zhang, D., Tian, L., \& Zeng, Y. (2012). Distribution of heavy metals in sediments of the Pearl River Estuary, Southern China: Implications for sources and historical changes. Environmental Sciences, 24(4), 579-588. 